\title{
The Influence of Body Mass on Whole-Body Vibration: A Quad-Bike Field Study
}

\author{
Ramakrishnan Mani, Stephan Milosavljevic ${ }^{*}$ and S. John Sullivan
}

\author{
Centre for Physiotherapy Research, School of Physiotherapy, University of Otago, PO Box 56, Dunedin, New Zealand.
}

\begin{abstract}
Objectives: The aim of this field study was to explore the relationship between body mass and quad bike induced whole-body vibration (WBV) exposure in a group of New Zealand rural workers.

Methods: WBV exposure was recorded using a seat pad mounted tri-axial accelerometer while rural workers $(\mathrm{n}=34)$ were driving a quad bike for approximately half an hour on a pre-marked track on farm terrain. Personal factors such as age, height and quad bike driving experience were also surveyed and included as co-variates. Vibration dose value (VDV) was calculated by analyzing the recorded raw vibration data samples $(n=34)$ using vibration analysis software and corrected to a one hour equivalent exposure for further statistical analysis. To evaluate for the relationship between variables of interest (body mass, height, age and driving experience) and one hour $\operatorname{VDV}_{\mathrm{Z}}\left(\mathrm{hrVDV}_{\mathrm{Z}}\right)$, univariate and multivariate linear regression analysis were conducted.

Results: Mean $1 \mathrm{hrVDV}_{\mathrm{Z}}$ was $13.2 \mathrm{~m} / \mathrm{s}^{1.75}$ exceeded the VDV exposure action value of $9.1 \mathrm{~m} / \mathrm{s}^{1.75}$. Univariate analysis demonstrated body mass $\left(\mathrm{R}^{2}=0.340\right)$ significantly $(\mathrm{p}<0.0003)$ associated with $1 \mathrm{hrVDV}_{\mathrm{Z}}$ while age, body height and quad bike driving experience were not. In a multivariate backward linear analysis body mass, height, and experience combined to explain $38 \%\left(\mathrm{R}^{2}=0.376\right)$ of the variance in $1 \mathrm{hr} \mathrm{VDV}_{\mathrm{Z}}$, however, only body mass $(\mathrm{p}=0.0004)$ demonstrated statistical significance.
\end{abstract}

Conclusion: Body mass is significantly and negatively associated with quad bike induced WBV (1hrVDV $)_{\mathrm{Z}}$ in a group of New Zealand rural workers.

Keywords: Whole-body vibration, body mass, vibration dose value, quad bikes.

\section{INTRODUCTION}

Although occupational whole-body vibration (WBV) has been identified as a risk factor for spinal musculoskeletal disorders and balance disturbances [1-3] dose response relationships have yet to be clearly determined $[4,5]$. Intrinsic and extrinsic factors are likely to be modulators of vibration induced injury risk. Intrinsic factors include: age, anthropometry (height, body mass, posture, experience and driving behavior). Extrinsic factors include: magnitude, frequency and duration of vibration exposure, nature of terrain, type of seat, seat and cabin suspension, tyre pressure and vehicle type [6].

In New Zealand more than 80,000 four wheel drive quad bikes are regularly used by rural workers for various farming purposes including stock mustering, personal transport and carriage of implements [7]. Recent literature suggests that on-farm use of a quad bike exposes rural workers to high levels of WBV $\left(\mathrm{VDV}_{\mathrm{Z}} \sim 17.0 \mathrm{~m} / \mathrm{s}^{1.75}\right)$ well above the recommended exposure action value of $9.1 \mathrm{~m} / \mathrm{s}^{1.75}$ [8-11]. Drivers of all-terrain vehicles (including quad bikes) are exposed to high levels of WBV and are known to experience low back pain (LBP) as well as pain in the neck, shoulder

*Address correspondence to this author at the Centre for Physiotherapy Research, School of Physiotherapy, University of Otago, PO Box 56, Dunedin, 9054, New Zealand; Tel: +64 3479 7193; Fax: +64 3479 8414; E-mail: stephan.milosavljevic@otago.ac.nz and thoracic regions [2, 8, 10, 12-14]. Although rural workers who use quad bikes are exposed to high levels of WBV and have a high prevalence of spinal pain $[8,10]$, not all workers report spinal complaints and thus musculoskeletal injury risk may also be associated with a combination of intrinsic and extrinsic factors.

Body mass (kgs) and body mass index (BMI) are commonly described intrinsic factors. Both excessive body mass and high BMI are considered as risk factors in the development of work-related musculoskeletal disorders such as LBP $[15,16]$. However, the evidence linking LBP to high body mass (or BMI) in professional drivers is conflicting $[17,18]$. Although high levels of WBV have been associated with occupational LBP, body mass may be an important intrinsic factor which modulates this relationship in different ways. Several laboratory studies (Table 1) have investigated the influence of body mass on various WBV exposure measures (including mechanical impedance, absorbed power, vibration transmission and apparent mass) under varying experimental conditions including; seat cushion, seat suspension, back rest, seat and tyre pressure, vibration magnitude and frequency [19-26] Extrapolation from these laboratory studies generally demonstrates negative associations between increased body mass and vibration exposure.

A small number of field studies (Table 2) have been conducted on urban taxi drivers, metropolitan bus drivers, 
Table 1. Laboratory Studies: Relationship Between Body Mass and Whole-Body Vibration Exposure

\begin{tabular}{|c|c|c|c|c|c|c|}
\hline $\begin{array}{l}\text { Author \& } \\
\text { Year }\end{array}$ & Objective & Study Participants & Data Collection Setup & $\begin{array}{l}\text { Outcome } \\
\text { Measure }\end{array}$ & $\begin{array}{c}\text { Data } \\
\text { Analysis }\end{array}$ & Results/Conclusion \\
\hline $\begin{array}{c}\text { Toward et al. } \\
2010 \text { [26] }\end{array}$ & \begin{tabular}{|} 
To determine \\
any association \\
between subject \\
characteristics \\
and the apparent \\
mass of the \\
human body on \\
VV
\end{tabular} & 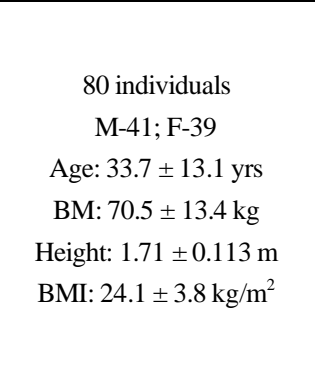 & $\begin{array}{c}\text { VG: electro-hydraulic vibrator } \\
\text { Acc (z-axis): } 0.5,1.0,1.5 \mathrm{~m} / \mathrm{s}^{2} \\
\text { Freq: } 0.6 \text { \& } 12 \mathrm{~Hz} \text { Conditions: } 4 \text { (with \& } \\
\text { without backrest: rigid \& foam/inclined \& } \\
\text { upright) } \\
\text { DE: } 60 \text { sec/condition } \\
\text { RL: FP as seat \& platform (A) }\end{array}$ & $\begin{array}{l}\text { Apparent } \\
\text { mass }\end{array}$ & $\begin{array}{l}\text { Multiple } \\
\text { Linear } \\
\text { regression }\end{array}$ & $\begin{array}{c}\text { BM is the strongest } \\
\text { predictor }(\beta=0.84, \\
0.92 \& 0.61) \text { of } \\
\text { apparent mass at } 0.6 \\
\text { Hz, at resonance \& at } \\
12 \mathrm{~Hz} \text {. } \\
\text { Increased BMI was } \\
\text { associated with a } \\
\text { decrease in } \\
\text { resonance frequency } \\
\text { of } 0.5 \text { to } 1.7 \mathrm{~Hz} .\end{array}$ \\
\hline $\begin{array}{c}\text { Rakheja et al. } \\
2008 \text { [24] }\end{array}$ & \begin{tabular}{|c|} 
To investigate \\
the absorbed \\
power \\
characteristics \\
under HV at two \\
driving points
\end{tabular} & $\begin{array}{c}8 \text { individuals } \\
\text { M- } 8 ; \text { F- } 0 \\
\text { Age: } 21-51 \text { yrs } \\
\text { BM: } 71.2 \pm 10.6 \mathrm{~kg} \\
\text { Height: } 1.73 \pm 0.025 \mathrm{~m} \\
\text { BMI: NS }\end{array}$ & $\begin{array}{c}\text { VG: HV simulator } \\
\text { Acc (x \& y-axis): } 0.25,0.5,1.0 \mathrm{~m} / \mathrm{s}^{2} \\
\text { Freq: } 0-10 \mathrm{~Hz} \\
\text { DE: NS } \\
\text { RL: platform \& seat back (A), seat pan \& back } \\
\text { rest (FP) }\end{array}$ & $\begin{array}{l}\text { Absorbed } \\
\text { power }\end{array}$ & $\begin{array}{l}\text { Single } \\
\text { factor } \\
\text { linear } \\
\text { regression } \\
\text { analysis }\end{array}$ & $\begin{array}{l}\text { Magnitude of the } \\
\text { absorbed power is } \\
\text { strongly correlated } \\
\left(\mathrm{R}^{2}>0.8\right) \\
\text { to subject's weight. }\end{array}$ \\
\hline $\begin{array}{l}\text { Wang et al. } \\
2006 \text { [23] }\end{array}$ & \begin{tabular}{|c|} 
To evaluate \\
energy \\
absorption \\
characteristics of \\
seated human \\
occupants \\
exposed to \\
vertical vibration \\
under different \\
postural \\
conditions
\end{tabular} & $\begin{array}{c}27 \text { individuals } \\
\text { M-13; F-14 } \\
\text { Age: } 39.6 \pm 8.5 \mathrm{yrs} \\
\text { BM: } 70 \pm 16 \mathrm{~kg} \\
\text { Height: } 170.9 \pm 7.13 \mathrm{~m} \\
\text { BMI: } 18.1 \pm 32.2 \mathrm{~kg} / \mathrm{m}^{2}\end{array}$ & $\begin{array}{r}\text { VG: whole body vertical simulator } \\
\text { Acc (z- axis): } 0.5 \text { to } 1.0 \mathrm{~m} / \mathrm{s}^{2} \\
\text { Freq: } 0.5-40 \mathrm{~Hz} \\
\text { Type of seat: rigid (off-road vehicle) } \\
\text { Postures: } 36 \text { (hands position, seat pan, back } \\
\text { support) } \\
\text { DE: NS } \\
\text { RL: seat (A)/between the seat and simulator } \\
\text { (FP) }\end{array}$ & $\begin{array}{l}\text { Absorbed } \\
\text { power }\end{array}$ & $\begin{array}{l}\text { Single } \\
\text { factor } \\
\text { linear } \\
\text { regression } \\
\text { analysis }\end{array}$ & $\begin{array}{c}\text { Magnitude of the } \\
\text { absorbed power is } \\
\text { strongly correlated to } \\
\text { individual's BM }\left(\mathrm{R}^{2}\right. \\
>0.94) \& \text { BMI }\left(\mathrm{R}^{2}\right. \\
>0.84) .\end{array}$ \\
\hline $\begin{array}{c}\text { Bluthner } \text { et al. } \\
2006 \text { [22] }\end{array}$ & \begin{tabular}{|} 
To investigate \\
the significance \\
of body mass \\
and vibration \\
magnitude on \\
seat \\
transmissibility
\end{tabular} & $\begin{array}{c}12 \text { individuals } \\
\text { M-12; F-0 } \\
\text { Age: } 31 \pm 11 \text { yrs } \\
\text { BM: } 75.4 \pm 11.4 \mathrm{~kg} \\
\text { Height: } 181.2 \pm 8.8 \mathrm{~m} \\
\text { BMI: NS }\end{array}$ & $\begin{array}{c}\text { VG: electro-hydraulic hexa pod } \\
\text { Acc (x axis): } 0.9-2.03 \text {; y axis: } 0.77-1.57 \mathrm{~m} / \mathrm{s}^{2} \\
\text { Freq: NS } \\
\text { Types of seat: } 2 \text { (truck \& tractor) } \\
\text { DE: } 2.8 \mathrm{~min} / 2 \text { trials } \\
\text { RL: platform/seat frame } / \mathrm{seat} \text { cushion/back rest } \\
\text { (A) }\end{array}$ & SEAT & $\begin{array}{l}\text { Univariate } \\
\& \text { multiple } \\
\text { linear } \\
\text { regression } \\
\text { analysis }\end{array}$ & $\begin{array}{c}\text { A significant } \\
\text { influence of the body } \\
\text { mass }\left(\mathrm{R}^{2}=0.8\right) \text { on } \\
\text { SEAT values was } \\
\text { found for y-direction } \\
\text { only. }\end{array}$ \\
\hline $\begin{array}{l}\text { Holmlund et } \\
\text { al. } 2000[21]\end{array}$ & \begin{tabular}{|c|} 
To investigate \\
the mechanical \\
impedance of the \\
human body \\
under vertical \\
vibration
\end{tabular} & $\begin{array}{c}30 \text { individuals } \\
15 \mathrm{M} \& 15 \mathrm{~F} \\
\text { Age: } 31 \pm 11 \\
\text { BM: } 70 \pm 11 \mathrm{~kg} \\
\text { Height: } 173 \pm 7 \mathrm{~m} \\
\text { BMI: NS }\end{array}$ & $\begin{array}{c}\text { VG: electrodynamic shaker } \\
\text { Acc (z-axis): } 0.5,0.7,1.0,1.4 \mathrm{~m} / \mathrm{s}^{2} \\
\text { Freq: } 2-100 \mathrm{~Hz} \\
\text { DE: } 20 \mathrm{~min} \\
\text { Posture: erect/relaxed upper body } \\
\text { RL: seat plate (A)/between the seat plate (FP) }\end{array}$ & $\begin{array}{c}\text { Mechanical } \\
\text { driving point } \\
\text { impedance } \\
\text { (z-axis) }\end{array}$ & $\begin{array}{l}\text { Linear } \\
\text { regression }\end{array}$ & $\begin{array}{c}\text { Magnitude of the } \\
\text { impedance is } \\
\text { strongly correlated } \\
\left(\mathrm{R}^{2}=0.8\right) \text { to subject's } \\
\text { weight up to about } 4 \\
\text { Hz. }\end{array}$ \\
\hline $\begin{array}{l}\text { Huston et al. } \\
1999 \text { [20] }\end{array}$ & \begin{tabular}{|} 
To determine if \\
the air cushions \\
affect the natural \\
resonance of the \\
seat in off-road \\
mining vehicles
\end{tabular} & $\begin{array}{c}3 \text { individuals } \\
\text { M/F: NS } \\
\text { Age: NS } \\
\text { BM: } 55 / 71 / 95 \mathrm{~kg} \\
\text { (LW-55, MW -71, HW-95) } \\
\text { Height: NS } \\
\text { BMI: NS }\end{array}$ & $\begin{array}{c}\text { VG: servo hydraulic Acc: NS } \\
\text { Freq: 1-10 Hz (representative of off-road } \\
\text { mining vehicles) } \\
\text { Type of seat: mechanical spring suspension } \\
\text { No of air cushions: } 5 \\
\text { DE: } 5 \text { min/ } 2 \text { trials } \\
\text { RL: seat base \& seat pad (A) }\end{array}$ & $\begin{array}{c}\text { Ratio of } \\
\text { transmission } \\
\text { in different } \\
\text { frequency } \\
\text { bands }\end{array}$ & NS & $\begin{array}{l}\text { LW: high resonance } \\
\quad(1-2.5 \mathrm{~Hz}), \\
\text { MW: low }(3-4 \mathrm{~Hz}) \& \\
\text { high }(>5 \mathrm{~Hz}), \\
\text { resonance, } \\
\text { HW: low resonance } \\
\quad(>3 \mathrm{~Hz}) .\end{array}$ \\
\hline $\begin{array}{l}\text { Lundstrom et } \\
\text { al. } 1998 \text { [25] }\end{array}$ & $\begin{array}{l}\text { To investigate } \\
\text { WBV energy } \\
\text { absorption } \\
\text { during different } \\
\text { experimental } \\
\text { conditions }\end{array}$ & $\begin{array}{c}60 \text { individuals }(\mathrm{VV} / \mathrm{HV}) \\
\text { M- } 15 ; \mathrm{F}-15 \\
\text { Age: } 31 \pm 11 / 37 \pm 11 \\
\text { BM: } 70 \pm 11 / 69 \pm 10 \mathrm{~kg} / \mathrm{m}^{2} \\
\text { Height: } 173 \pm 7 / 172 \pm 27 \mathrm{~m} \\
\text { BMI: NS }\end{array}$ & $\begin{array}{l}\text { VG: electrodynamic shaker } \\
\text { Acc-z-axis: } 0.5,0.7,1.0,1.4 \mathrm{~m} / \mathrm{s}^{2} ; \mathrm{x}, \mathrm{y} \text {-axis: } \\
0.25,0.35,0.5,0.7,1.0,1.4 \mathrm{~m} / \mathrm{s}^{2} \\
\text { Freq: } 2-80 \text { (z-axis) \& } 1.13-80 \mathrm{~Hz} \text { (x,y-axis) } \\
\text { DE: HV-3,VV-10 min } \\
\text { RL: seat plate (A/FP) }\end{array}$ & $\begin{array}{l}\text { Absorbed } \\
\text { power }\end{array}$ & $\begin{array}{l}\text { ANOVA \& } \\
\text { Wilcoxon } \\
\text { non- } \\
\text { parametric } \\
\text { method }\end{array}$ & $\begin{array}{l}\text { Absorbed power } \\
\text { increased with the } \\
\text { body weight more } \\
\text { specifically in } \\
\text { females. }\end{array}$ \\
\hline
\end{tabular}




\begin{tabular}{|c|c|c|c|c|c|c|}
\hline $\begin{array}{c}\text { Author \& } \\
\text { Year }\end{array}$ & Objective & Study Participants & Data Collection Setup & $\begin{array}{l}\text { Outcome } \\
\text { Measure }\end{array}$ & $\begin{array}{c}\text { Data } \\
\text { Analysis }\end{array}$ & Results/Conclusion \\
\hline $\begin{array}{c}\text { Burdorf } \\
\text { et al. } 1993 \\
{[19]}\end{array}$ & $\begin{array}{l}\text { To evaluate the } \\
\text { effect of seat } \\
\text { suspension on } \\
\text { the driver's } \\
\text { exposure to } \\
\text { vibration }\end{array}$ & $\begin{array}{c}2 \text { individuals } \\
\text { M/F: NS } \\
\text { Age: NS } \\
\text { BM: 53/95 kg } \\
\text { Height: NS } \\
\text { BMI: NS }\end{array}$ & $\begin{array}{c}\text { VG: NS } \\
\text { Acc (z-axis): } 2.05 \mathrm{~m} / \mathrm{s}^{2} \text { (tractors) } 0.95 \mathrm{~m} / \mathrm{s}^{2} \\
\text { (lorry); } 1.00 \mathrm{~m} / \mathrm{s}^{2} \text { (fork-lift) } \\
\text { Freq: NS } \\
\text { No of suspended seats: } 11 \\
\text { DE: } 5 \mathrm{~min} / 3 \text { trials } \\
\text { RL: seat surface/floor of the vehicle (A) }\end{array}$ & $\begin{array}{l}\text { Tz \& seat } \\
\text { level RMS } \\
\text { acceleration } \\
\text { (z-axis) }\end{array}$ & NS & $\begin{array}{l}\text { Tz significantly low } \\
\text { in a specific } \\
\text { suspended seat with } \\
95 \mathrm{~kg} \text { volunteer than } \\
\text { with } 53 \mathrm{~kg} \text { subject. }\end{array}$ \\
\hline
\end{tabular}

M- males, F- females, BM- body mass, WBV- whole body vibration, HV- horizontal vibration, VV- vertical vibration, A-accelerometer, FP-force plate, DE: duration of exposure, SEAT- seat effective amplitude transmissibility, Tz- vibration transmission coefficient, RMS- root mean square, Sed- static compression dose, VDV- vibration dose value, VG: vibration generator, RL- level of vibration/force recording, NS- not specified, LW- light weight, MW- medium weight, HW- heavy weight.

and fork-lift truck drivers. While four studies [27-30] demonstrated a casual observation to significant negative association between body mass and vibration exposure the other two studies found no such relationship [19,31]. While our recent quad bike research [8-10] has not identified body mass as being associated with WBV this was not the primary aim of these projects which were undertaken on a variety of different farms, terrains, quad bikes, and with different groups of workers. Thus, it is possible that these extrinsic factors contributed sufficiently to obscure the influence of body mass.

The primary aim of this field study was to explore the relationship between body mass and quad bike WBV exposure in a group of New Zealand rural workers when controlling for such extrinsic factors. The secondary aim was to explore personal factors such as age, height and quad bike driving experience as co-variates to determine whether these are also associated with exposure.

\section{MATERIALS AND METHODS}

\subsection{Study Design}

A cross sectional observational study was conducted on a South Otago (New Zealand) sheep and beef farm to investigate the relationship between body mass and vibration exposure in a group of rural workers $(n=34$ males; age $=18$ to 60 years) who regularly use quad bikes. This study was approved by the University of Otago Human Ethics committee. This study was a part of a larger project designed to investigate balance disturbances following exposure to a period of quad bike induced WBV.

\subsection{Recruitment}

Inclusion criteria were: currently working full time, in good health with no history of significant illness or injury to spine or limbs which required clinical intervention in the past 6 months. A convenience sample of 39 full time male rural workers was contacted by using publicly available community resources, including farm location maps. For practical reasons recruitment started near the provincial township of Balclutha, spreading outwards. Farms were contacted by telephone to describe the study, and seek verbal agreement by the worker to participate in the survey and recording of vibration exposure. In this manner 34 workers agreed to participate in the study.

\subsection{Survey}

On the day of experiment, each participant was surveyed to ensure they met the inclusion criteria and provided written informed consent to participate in the study. The survey also recorded self-reported age (yrs), height (m), weight (kgs), quad bike driving experience (years), and average daily driving period (hours). BMI was calculated by dividing body mass (kgs) by the square of height $(\mathrm{m})$ [32].

\subsection{Experiment Setup}

\subsubsection{ATV and Test Route}

A commonly used 4 wheel drive quad bike (Fig. 1, Yamaha Big Bear 400) with a fixed arm, single shock absorber rear suspension, and a fully independent front suspension, was chosen for the whole-body vibration exposure. Immediately prior to use, the vehicle was serviced by a trained mechanic and tire pressure set and maintained at the manufacturers recommended inflation pressure of 20.7 $\mathrm{kPa}$ (or $3.0 \mathrm{psi}$ ). Each participant drove the quad bike over the same pre-defined track. Following a consensus discussion with an experienced local farmer this track was chosen to represent a typical example of New Zealand mixed stock rolling farmland. This test route included a mixture of (farmer defined) flat, rolling flat, hilly and steep hilly terrains that included both paddocks and farm tracks [10]. The total distance of the track was 10.0 kilometres with each worker asked to drive over the same track in approximately 30 minutes to complete the circuit at an average vehicle velocity not to exceed $20 \mathrm{~km} /$ hour. The 30 minute period of vibration exposure was chosen by calculating the mean of the longest epoch of continuous driving gathered from 30 participants who took part in a previous full day quad bike vibration exposure study [9]. This recommended time, distance and average velocity were confirmed by the landowner after repeated trials driving over the test route at normal work speed.

\subsubsection{Whole-Body Vibration Exposure}

On arrival at the experimental site all participants were given specific driving instructions which include: nature of the test route using a farm map, to remain in a seated position, to drive at a speed not exceeding $20 \mathrm{~km} / \mathrm{hour}$, to not stop or dismount from the vehicle until the completion of the test ride. Each participant was also asked to sit (ischial 
Table 2. Field Studies: Relationship Between Body Mass and Whole-Body Vibration Exposure

\begin{tabular}{|c|c|c|c|c|c|c|}
\hline $\begin{array}{c}\text { Author \& } \\
\text { Year }\end{array}$ & Objective & Study Participants & Data Collection Setup & $\begin{array}{l}\text { Outcome } \\
\text { Measure }\end{array}$ & $\begin{array}{c}\text { Data } \\
\text { Analysis }\end{array}$ & $\begin{array}{l}\text { Results/Conclusi } \\
\text { on }\end{array}$ \\
\hline $\begin{array}{c}\text { Blood et } \\
\text { al. 2010 } \\
\text { [31] }\end{array}$ & $\begin{array}{l}\text { To determine } \\
\text { any differences } \\
\text { in WBV } \\
\text { exposures } \\
\text { based on body } \\
\text { weight and seat } \\
\text { pressure } \\
\text { settings in } \\
\text { metropolitan } \\
\text { bus drivers }\end{array}$ & $\begin{array}{c}12 \text { part/full time bus drivers } \\
\text { Age: } 50.8 \pm 6.8 \mathrm{yrs} \\
\text { M- } 6 \text {; F- } 6 \\
\text { BM: } 80.9 \pm 19.8 \mathrm{~kg} \\
\text { Light }(<70 \mathrm{~kg}): 5 ; \\
\text { Moderate }(71-93 \mathrm{~kg}): 4 ; \\
\text { Heavy }(>94 \mathrm{~kg}): 3 \\
\text { Height: NS } \\
\text { BMI: NS } \\
\text { DE: } 9.9 \pm 9.3 \mathrm{yrs} \\
\text { DT: } 5.5 \pm 1.9 \mathrm{hrs}\end{array}$ & $\begin{array}{c}\text { Vehicle: ST } \\
\text { (Same low floor bus/no } \\
\text { passenger) } \\
\text { Track: ST } \\
\text { Distance: } 52 \mathrm{~km} \text { including } 10 \\
\text { speed humps } \\
\text { Speed/duration: NST } \\
\text { RL: seat \& floor of the bus }\end{array}$ & $\begin{array}{l}\text { VDV, RMS } \\
\text { acceleration, } \\
\text { Sed, } \\
\text { acceleration } \\
\text { peak \& } \\
\text { SEAT }\end{array}$ & $\begin{array}{l}\text { Repeated } \\
\text { measures } \\
\text { ANOVA }\end{array}$ & $\begin{array}{l}\text { No significant } \\
\text { weight related } \\
\text { behavior across } \\
\text { seat and road } \\
\text { types. }\end{array}$ \\
\hline $\begin{array}{c}\text { Blood et } \\
\text { al. 2010 } \\
\text { [30] }\end{array}$ & $\begin{array}{l}\text { To compare } \\
\text { the differences } \\
\text { in WBV } \\
\text { exposure } \\
\text { between } 2 \\
\text { types of } \\
\text { suspensions in } \\
\text { fork-lift } \\
\text { operators }\end{array}$ & $\begin{array}{c}12 \text { fork-lift operators } \\
\text { M/F: NS } \\
\text { Age: } 44.3 \pm 11.6 \mathrm{yrs} \\
\text { BM: } 98.3 \pm 19.4 \mathrm{~kg} \\
\text { Height: NS } \\
\text { BMI: } 31.0 \pm 4.7 \mathrm{~kg} / \mathrm{m}^{2} \\
\text { DE: } 17.7 \pm 13.9 \mathrm{yrs} \\
\text { DT: NS }\end{array}$ & $\begin{array}{c}\text { Vehicle: ST } \\
\text { (Same fork-lift) } \\
\text { Track: ST } \\
\text { Types of suspension: mechanical } \\
\text { \& air suspension } \\
\text { Distance: } 3.5 \mathrm{~km} \\
\text { Speed: NST } \\
\text { Recording duration: } 12-15 \mathrm{~min} \\
\text { RL: seat \& floor }\end{array}$ & $\begin{array}{l}\text { VDV, RMS } \\
\text { acceleration, } \\
\text { Sed, } \\
\text { acceleration } \\
\text { peak \& } \\
\text { SEAT }\end{array}$ & $\begin{array}{c}\text { Repeated } \\
\text { measures } \\
\text { ANOVA \& } \\
\quad \text { non- } \\
\text { parametric } \\
\text { Wilcoxon } \\
\text { rank-sum } \\
\quad \text { tests }\end{array}$ & $\begin{array}{l}\text { WBV exposure } \\
\text { decreased with } \\
\text { body mass in } \\
\text { mechanical seat } \\
\& \text { better } \\
\text { exposure } \\
\text { reduction in } \mathrm{LW} \\
\text { drivers }(<84 \mathrm{~kg}) \\
\text { under air } \\
\text { suspension. }\end{array}$ \\
\hline $\begin{array}{c}\text { Chang et } \\
\text { al. 2003 } \\
{[29]}\end{array}$ & $\begin{array}{l}\text { To identify } \\
\text { important } \\
\text { WBV } \\
\text { predictors to } \\
\text { quantify } \\
\text { individual } \\
\text { WBV exposure } \\
\text { among urban } \\
\text { taxi drivers }\end{array}$ & $\begin{array}{c}247 \text { taxi drivers } \\
\text { M-247, F- } 0 \\
\text { Age: } 44.6 \pm 8.3 \mathrm{yrs} \\
\text { BM: } 68.9 \pm 11.8 \mathrm{~kg} \\
\text { Height: NS } \\
\text { BMI: NS } \\
\text { DE: } 9.2 \pm 7.3 \mathrm{yrs} \\
\text { DT: } 9.7 \pm 2.3 \mathrm{hrs}\end{array}$ & $\begin{array}{c}\text { Vehicle: ST } \\
\text { (Different models of taxi) } \\
\text { Track: NST } \\
\text { Usual taxi driving practices; } \\
\text { different traffic hours; } \\
\text { vacant/short/long rides; Usual } \\
\text { speed \& driving patterns: NST } \\
\text { Distance: NS } \\
\text { Recording duration: } 30 \text { min } \\
\text { RL: seat level }\end{array}$ & $\begin{array}{c}\text { RMS } \\
\text { acceleration } \\
\text { (Z axis) }\end{array}$ & $\begin{array}{l}\text { Mixed } \\
\text { effects } \\
\text { model; } \\
\text { Likelihood } \\
\text { ratio test \& } \\
\text { covariate } \\
\text { entering the } \\
\text { model: } 0.20 \\
\text { level }\end{array}$ & $\begin{array}{c}\text { Body weight is a } \\
\text { highly significant } \\
(\mathrm{p}=0.002) \\
\text { predictor of } \\
\text { WBV exposure } \\
\text { in urban taxi } \\
\text { drivers. }\end{array}$ \\
\hline $\begin{array}{c}\text { Malchaire } \\
\text { et al. } 1995 \\
{[28]}\end{array}$ & $\begin{array}{l}\text { To compare } \\
\text { the influence } \\
\text { of cushion and } \\
\text { inflated tyres } \\
\text { on vibration } \\
\text { exposure in } \\
\text { fork-lift trucks }\end{array}$ & $\begin{array}{c}3 \text { skilled fork-lift drivers } \\
\text { Age: NS } \\
\text { BM: 72/55/72 kg } \\
\text { Height: NS } \\
\text { BMI: NS }\end{array}$ & $\begin{array}{c}\text { Vehicle: NST } \\
5 \text { types of fork-lift trucks; } \\
4 \text { - types of tyres, } 2 \text { - types of } \\
\text { seat; 2- loaded/unloaded } \\
\text { conditions } \\
\text { Track: ST } \\
\text { Rough }(300 \mathrm{~m}) \text { \& smooth }(280 \\
\text { m) tracks } \\
\text { Instructed drive 'as usual' } \\
\text { Speed: ST } \\
\text { Duration of ride: NS } \\
\text { RL: seat \& floor of the vehicle }\end{array}$ & $\begin{array}{l}\text { Seat \& floor } \\
\text { RMS } \\
\text { acceleration }\end{array}$ & $\begin{array}{l}\text { ANOVA \& } \\
\text { multiple } \\
\text { regression } \\
\text { analysis }\end{array}$ & $\begin{array}{c}\text { Casual } \\
\text { observation: high } \\
\text { RMS } \\
\text { acceleration in } 55 \\
\text { kg individual and } \\
\text { low RMS in the } \\
72 \mathrm{~kg} \text { individual. } \\
\text { Regression } \\
\text { coefficient } \\
\text { (0.138) No effect } \\
\text { of worker's } \\
\text { weight on seat } \\
\text { vibration. }\end{array}$ \\
\hline $\begin{array}{c}\text { Burdorf et } \\
\text { al. } 1993 \\
{[19]}\end{array}$ & $\begin{array}{l}\text { To evaluate the } \\
\text { effectiveness } \\
\text { of seat } \\
\text { suspension on } \\
\text { vibration } \\
\text { transmissibility } \\
\text { through the } \\
\text { driver's seat of } \\
\text { lorries, tractors } \\
\text { \& fork-lift } \\
\text { trucks }\end{array}$ & $\begin{array}{c}2 \text { participants } \\
\text { Age: NS } \\
\text { BM: } 53 \& 95 \mathrm{~kg} \\
\text { Height: NS } \\
\text { BMI: NS } \\
\text { DE/DT: NS }\end{array}$ & $\begin{array}{c}\text { Vehicle: NST (lorries, tractors \& } \\
\text { fork-lift) } \\
11 \text { types of seats } \\
\text { Track: ST } \\
24 \text { working environments } 2 \\
\text { working conditions: high speed } \\
\text { on smooth terrain; low speed on } \\
\text { rough terrain } \\
\text { Distance: NS } \\
\text { Speed: ST } \\
\text { Duration of ride: ST (5 min) } \\
\text { RL: seat \& floor of the vehicle }\end{array}$ & $\begin{array}{l}\text { Tz \& seat } \\
\text { level RMS } \\
\text { acceleration } \\
\text { ( } \mathrm{z} \text { axis) }\end{array}$ & NS & $\begin{array}{c}\text { Tz \& RMS } \\
\text { acceleration are } \\
\text { not dependent on } \\
\text { driver's weight. }\end{array}$ \\
\hline
\end{tabular}




\begin{tabular}{|c|c|c|c|c|c|c|}
\hline $\begin{array}{l}\text { Author \& } \\
\text { Year }\end{array}$ & Objective & Study Participants & Data Collection Setup & $\begin{array}{l}\text { Outcome } \\
\text { Measure }\end{array}$ & $\begin{array}{c}\text { Data } \\
\text { Analysis }\end{array}$ & $\begin{array}{c}\text { Results/Conclusi } \\
\text { on }\end{array}$ \\
\hline $\begin{array}{c}\text { Boileau et } \\
\text { al. } 1990 \\
\text { [27] }\end{array}$ & $\begin{array}{l}\text { To evaluate the } \\
\text { effect of } 4 \\
\text { suspension } \\
\text { seats on WBV } \\
\text { exposure in log } \\
\text { skidders in the } \\
\text { forest industry }\end{array}$ & $\begin{array}{c}2 \text { participants } \\
\text { Age: NS } \\
\text { BM: } 77 \& 102 \mathrm{~kg} \text { Height: NS } \\
\text { BMI: NS } \\
\text { DE/DT: NS }\end{array}$ & $\begin{array}{c}\text { Vehicle: NST } \\
\text { Track: NST } \\
\text { Typical terrains but in different } \\
\text { terrains. } \\
\text { Distance: NS } \\
\text { Speed: ST } \\
\text { Duration of ride: ST ( } 5 \text { min) } \\
\text { RL: seat \& floor of the vehicle }\end{array}$ & $\begin{array}{l}\text { SEAT, } \\
\text { weighted } \\
\text { overall } \\
\text { excitation } \\
\text { amplitude; } \\
\text { expected } \\
\text { daily } \\
\text { exposure } \\
\text { time }\end{array}$ & NS & $\begin{array}{l}\text { Lighter } \\
\text { individuals had } \\
\text { higher exposure } \\
\text { amplitude. }\end{array}$ \\
\hline
\end{tabular}

M- males, F- females, BM- body mass, WBV- whole body vibration, DE- driving experience, DT- driving duration/day, HV- horizontal vibration, VV- vertical vibration, SEAT- seat effective amplitude transmissibility, Tz- vibration transmission coefficient, RMS- root mean square, Sed- static compression dose, VDV- vibration dose value, RL-Level of vibration recording, NS- not specified, ST- standardized, NST- not standardized, LW- light weight, MW- medium weight, HW- heavy weight

tuberosities on the accelerometer pad) in their normal seated driving posture and to complete a continuous quad bike driving epoch for approximately 30 minutes on the premarked test route. Raw vibration data collected continuously during the 30 minute drive were accepted as satisfying the minimum 20 minute recording time conditions described within the ISO 2631-1 (1997) and ISO 2631-5 (2004) standards. A circular seat-pad containing a series $2(10 \mathrm{~g})$, 8th order, 1.2 elliptic, tri-axial accelerometer (NEXGEN Ergonomics) was mounted on the seat of the quad bike directly under each participant's ischial tuberosities. The accelerometer channels $\mathrm{X}, \mathrm{Y}$ and $\mathrm{Z}$ were aligned as anteriorposterior, medio-lateral, and superior inferior respectively with regards to the quad bike. Thus, the $\mathrm{X}$ channel recorded vibrations in a fore and aft direction, $Y$ recorded side to side vibrations and $\mathrm{Z}$ recorded vertical vibrations. Vibration data were digitally recorded, stored, and time stamped in a Biometrics (DataLog W4X8) 8 channel data logger (Biometrics ${ }^{\mathrm{TM}}$ ) mounted on the rear of the quad bike. In order to analyze a 0.5 to $80 \mathrm{~Hz}$ ISO 2631 recommended vibration spectrum the sampling frequency was set at 2000 $\mathrm{Hz}$ with an 8th order anti-aliasing filter set at the $500 \mathrm{~Hz}$ cutoff frequency as recommended by the supplier (NEXGEN Ergonomics Inc).

\subsection{Outcome Measure and Analysis}

\subsubsection{Vibration Outcome Measure}

As quad bike vibration exposure has previously demonstrated crest factors exceeding 9.0 [8] the vibration dose value (VDV) was chosen as the most appropriate quantitative measure of vibration exposure. The VDV (expressed in $\mathrm{m} / \mathrm{s}^{1.75}$ ) is considered to be a more sensitive indicator of the relationship between vibration magnitude and discomfort. It is also specifically sensitive to impulse vibration and also allows analysis of lower vibration magnitude for durations shorter than 8 hours [5, 33]. In accordance with the recommendations of the European Union Physical Agents Vibration Directive (EUPA (V)D) (2002) for daily exposure health effects a VDV score < $9.1 \mathrm{~m} / \mathrm{s}^{1.75}$ would be below the exposure action value (EAV) and a score $\geq 21.0 \mathrm{~m} / \mathrm{s}^{1.75}$ would be above the exposure limit value (ELV).

\subsubsection{Vibration Data Analysis}

Vibration dose values $\left(\mathrm{VDV}_{\mathrm{X}, \mathrm{Y}, \mathrm{Z}}\right.$ and sum $)$ were calculated using VATS ${ }^{\mathrm{TM}}$ (V3.4.4) proprietary vibration analysis software supplied by NEXGEN Ergonomics Inc. The $0.5 \mathrm{~Hz}$ to $80.0 \mathrm{~Hz}$ peak frequency spectrum was calculated by using a $1 / 3$ octave analysis Fast Fourier Transform (FFT) of the X, $\mathrm{Y}$ and $\mathrm{Z}$ axis peak RMS acceleration data. This allowed the determination of exposure to spinal resonant frequencies [33]. Low amplitude (non-driving) data were removed from the beginning and end of each participant's vibration log with the use of Biometrics DataLog software allowing the calculation of mean exposure period (driving duration). In order to control for the effect of variation in driving time, each participant's $\mathrm{VDV}_{\mathrm{Z}}$ was corrected to a one hour equivalent exposure, One hour $V D V_{Z}\left(1 h r V D V_{Z}\right)$ for further statistical analysis. Mean driving velocity $(\mathrm{km} / \mathrm{h})$ for each worker was also calculated by dividing distance travelled (10 $\mathrm{km}$ ) by mean driving time (hrs).

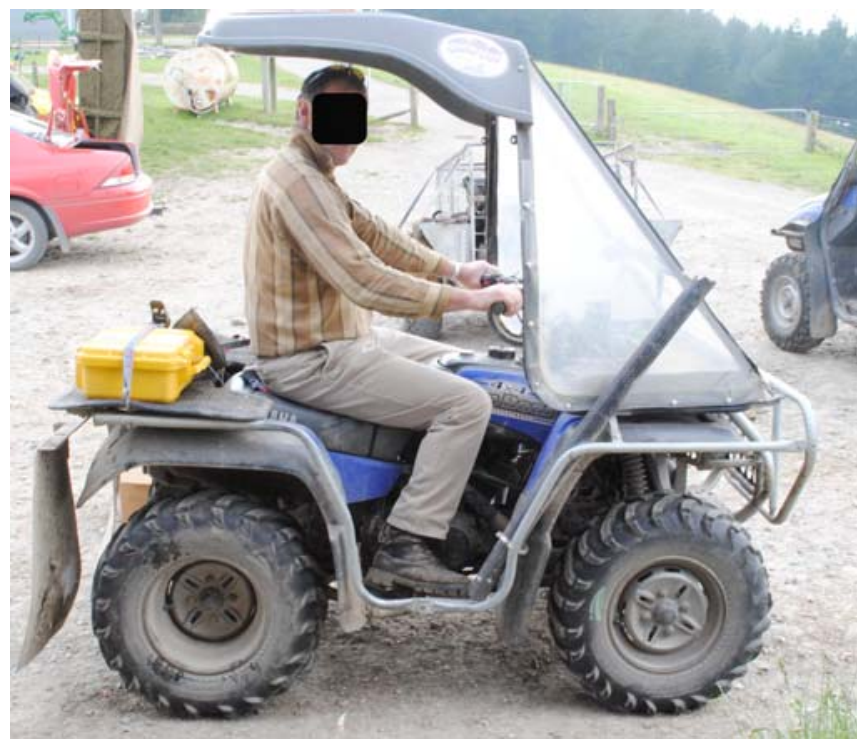

Fig. (1). Quad bike (Yamaha Big Bear 400).

\subsubsection{Data Analysis}

All data were analyzed using SPSS (version 16.0) and are presented descriptively in both tabular and graphic format. A univariate linear regression model included $1 \mathrm{hrVDV} V_{Z}$ $\left(\mathrm{m} / \mathrm{s}^{1.75}\right)$ as the dependent variable while Body mass $(\mathrm{kgs})$, Body height (m), Age (yrs) and Quad bike driving experience (yrs) were entered separately as independent variables. A multivariate backward linear regression model was also used to determine the influence of Body mass, Body height and Quad bike driving experience as co-variates. 


\section{RESULTS}

\subsection{Participant Information}

Participants had a mean age of 40.3 (yrs), mean body mass of $94.9(\mathrm{kgs})$, mean body height of $1.80(\mathrm{~m})$, mean BMI of $29.0\left(\mathrm{~kg} / \mathrm{m}^{2}\right)$, with a self-reported quad bike driving experience of 19.2 (yrs) and a daily quad bike driving duration of 2.2 hours. The mean recorded vibration exposure duration (hrs) was 0.5 hours and the mean driving velocity was $19.8 \mathrm{~km} / \mathrm{hr}$ (Table 3 ).

Table 3. Participant and Vehicle Exposure Information

\begin{tabular}{|c|c|c|c|c|}
\hline & Mean & Std. Deviation & Minimum & Maximum \\
\hline \hline Participant & 40.3 & 10.6 & 18.0 & 57.0 \\
\hline Age (yrs) & 94.9 & 14.0 & 68.0 & 129.0 \\
\hline Body mass (kgs) & 1.80 & 0.08 & 1.60 & 2.00 \\
\hline Body height (m) & 29.0 & 3.5 & 22.8 & 42.1 \\
\hline BMI (kg/m $\left.{ }^{2}\right)$ & 19.2 & 7.7 & 2.0 & 30.0 \\
\hline Driving experience (yrs) & 2.2 & 1.2 & 0.5 & 4.5 \\
\hline Daily driving (hrs) & &
\end{tabular}

\section{Vehicle Exposure}

\begin{tabular}{|c|c|c|c|c|}
\hline Exposure duration $(\mathrm{hrs})$ & 0.5 & 0.1 & 0.4 & 0.6 \\
\hline Driving velocity $(\mathrm{km} / \mathrm{hr})$ & 19.8 & 2.4 & 16.0 & 27.0 \\
\hline $\operatorname{VDV}_{\mathrm{X}}\left(\mathrm{m} / \mathrm{s}^{1.75}\right)$ & 5.7 & 0.6 & 4.2 & 6.7 \\
\hline $\operatorname{VDV}_{\mathrm{Y}}\left(\mathrm{m} / \mathrm{s}^{1.75}\right)$ & 5.5 & 0.4 & 5.0 & 6.8 \\
\hline $\operatorname{VDV}_{\mathrm{Z}}\left(\mathrm{m} / \mathrm{s}^{1.75}\right)$ & 11.1 & 1.6 & 8.0 & 15.4 \\
\hline $\operatorname{VDV}_{\text {sum }}\left(\mathrm{m} / \mathrm{s}^{1.75}\right)$ & 12.4 & 1.4 & 9.3 & 16.0 \\
\hline $1 \mathrm{hrVDV}_{\mathrm{Z}}\left(\mathrm{m} / \mathrm{s}^{1.75}\right)$ & 13.2 & 1.8 & 9.5 & 18.7 \\
\hline
\end{tabular}

\subsection{Vibration Dose Value}

Mean $\operatorname{VDV}_{\mathrm{X}}$ was $5.7 \mathrm{~m} / \mathrm{s}^{1.75}$, mean $\operatorname{VDV}_{\mathrm{Y}} 5.5 \mathrm{~m} / \mathrm{s}^{1.75}$, mean $\operatorname{VDV}_{\mathrm{Z}} 11.1 \mathrm{~m} / \mathrm{s}^{1.75}$ and mean $\operatorname{VDV}_{\text {sum }} 12.4 \mathrm{~m} / \mathrm{s}^{1.75}$ (Table 3 and Fig. 2). Mean one hour $\operatorname{VDV}_{Z}(1 \mathrm{hrVDV}$ ) was $13.2 \mathrm{~m} / \mathrm{s}^{1.75}$ (Table 3 and Fig. 3). Both $\mathrm{VDV}_{\mathrm{Z}}$ and $\mathrm{VDV}_{\text {sum }}$ exceeded the VDV exposure action value (EAV) of 9.1 $\mathrm{m} / \mathrm{s}^{1.75}$ for all participants (Fig. 3) although none exceeded the VDV exposure limit value of $21.0 \mathrm{~m} / \mathrm{s}^{1.75}$.

\subsection{FFT Spectrum}

Mean peak FFT values and amplitude characteristics for $\mathrm{X}, \mathrm{Y}$ and $\mathrm{Z}$ directions are presented in Fig. (4). The highest peak amplitude was $3.72 \mathrm{~m} / \mathrm{s}^{2}$ in the $\mathrm{Z}$ axis occurring at $4.0 \mathrm{~Hz}$ and considerably greater than the peak amplitudes observed at $2.5 \mathrm{~Hz}$ for the $X\left(2.34 \mathrm{~m} / \mathrm{s}^{2}\right)$ and $Y\left(1.68 \mathrm{~m} / \mathrm{s}^{2}\right)$ directions respectively.

\section{4. $\mathrm{VDV}_{\mathrm{Z}}$ Relationships}

Body mass demonstrated a statistically significant $(\mathrm{p}=$ 0.0003 ) univariate association (Table $\mathbf{4}$ and Fig. 5) with $1 h r V D V_{Z}\left(R^{2}=0.340\right)$ while Body height, Age and Quad bike driving experience did not. Further analysis also showed BMI was significantly associated $\left(\mathrm{p}=0.0003 ; R^{2}=0.337\right)$ with $1 \mathrm{hr} \operatorname{VDV}_{\mathrm{Z}}$ (Fig. 6) however the strength of the association was similar than that for Body mass alone. In a multivariate backward linear model (Table 4) Body mass, height, and Quad bike driving experience combined to explain $38 \%\left(R^{2}=0.376\right)$ of the variance in $1 \mathrm{hrVDV} V_{Z}$, however only Body mass $(\mathrm{p}=0.0004)$ demonstrated statistical significance.

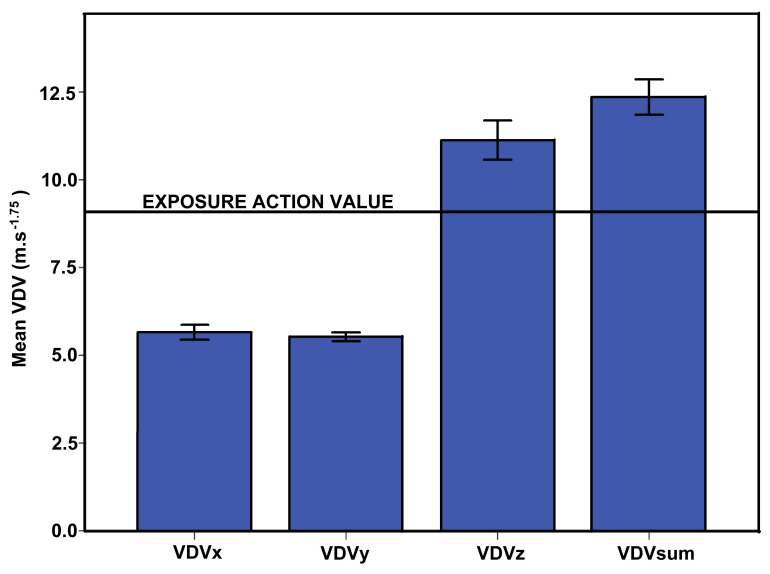

Fig. (2). Mean $\operatorname{VDV}_{X, Y, Z}$ and sum $\left(\mathrm{m} / \mathrm{s}^{1.75}\right)$ (error bars represent $95 \%$ confidence intervals).

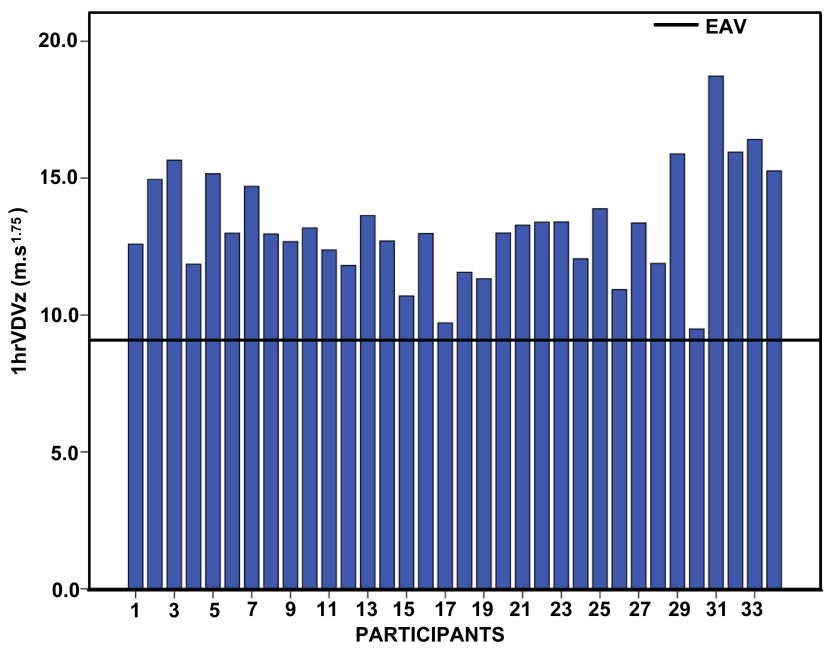

EAV $=$ Exposure Action value: $9.1 \mathrm{~m} / \mathrm{s}^{1.75}$

Fig. (3). $1 \mathrm{hrVDV}_{\mathrm{Z}}$ of the 34 participants.

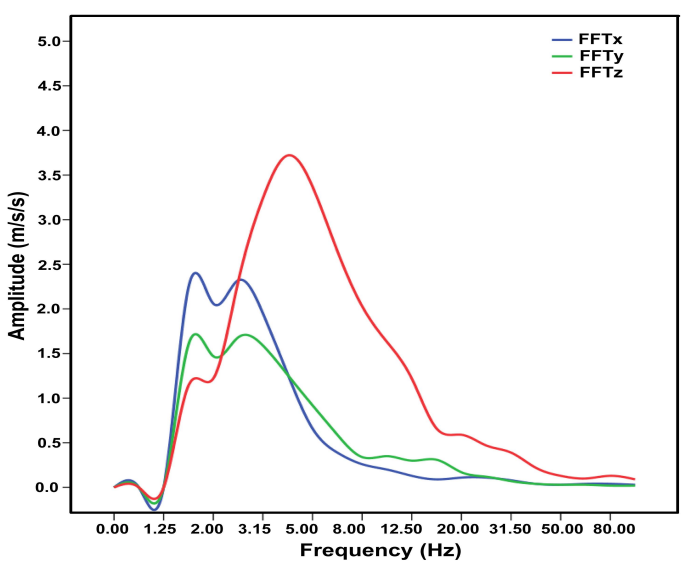

Fig. (4). FFT vibration spectrum. 
Table 4. Uni and Multivariate Regression Analysis for $\mathbf{1 h r V D V}_{Z}$ Exposure

\begin{tabular}{|c|c|c|c|c|c|}
\hline \multirow{2}{*}{ Univariate } & \multicolumn{5}{|c|}{$1 h r V D V_{Z}$} \\
\hline & $\boldsymbol{\beta}$ & Lower Bound & Upper Bound & p Value & $\mathbf{R}^{2}$ \\
\hline Age & 0.197 & -0.030 & 0.105 & 0.263 & 0.039 \\
\hline Body Mass & -0.583 & -0.123 & -0.041 & 0.0003 & 0.340 \\
\hline Body height & -0.198 & -13.570 & 3.829 & 0.262 & 0.039 \\
\hline BMI & -0.581 & -0.488 & -0.161 & 0.0003 & 0.337 \\
\hline Quad bike experience & -0.039 & -0.108 & 0.087 & 0.828 & 0.001 \\
\hline \multicolumn{6}{|l|}{ Multivariate } \\
\hline Body mass & -0.721 & -0.153 & -0.050 & 0.0004 & 0.340 \\
\hline Body height & 0.231 & -3.466 & 14.827 & 0.214 & 0.035 \\
\hline Quad bike experience & -0.020 & -0.086 & 0.075 & 0.891 & 0.001 \\
\hline Combined model & & & & & 0.376 \\
\hline
\end{tabular}

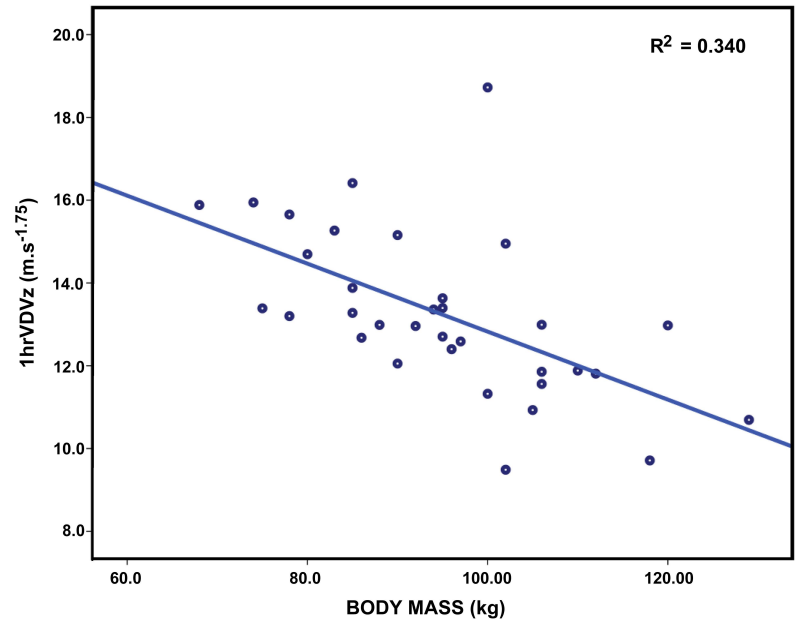

Fig. (5). Strength of association: Body mass (kg) and $1 \mathrm{hrVDV}_{\mathrm{Z}}$ $\left(\mathrm{m} / \mathrm{s}^{1.75}\right)$.

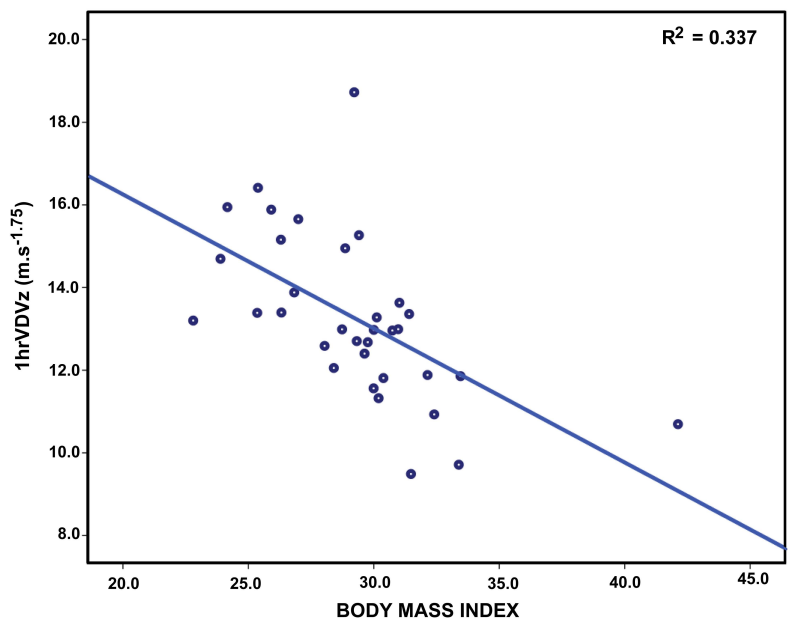

Fig. (6). Strength of association: BMI $\left(\mathrm{kg} / \mathrm{m}^{2}\right)$ and $1 \mathrm{hrVDV}_{\mathrm{Z}}$ $\left(\mathrm{m} / \mathrm{s}^{1.75}\right)$.

\section{DISCUSSION}

The aim of this field study was to explore the relationship between body mass and WBV exposure in a group of New Zealand rural workers who use quad bikes. The results demonstrate a significant negative association $\left(R^{2}=0.34\right)$ between body mass and $1 \mathrm{hrVDV}_{\mathrm{Z}}$ (Fig. 5). Consistent with other quad bike vibration research [8-10], this study has demonstrated high levels of vibration exposure in the $\mathrm{Z}$ direction exceeding the EAV of $9.1 \mathrm{~m} / \mathrm{s}^{1.75}$ [11] when driving for a mean 30 minutes of exposure. As vibration exposure was considerably lower than the $\operatorname{EAV}\left(<9.1 \mathrm{~m} / \mathrm{s}^{1.75}\right)$ in the $\mathrm{X}$ and $\mathrm{Y}$ directions these results primarily discuss risk and modulation associated with vibration in the $\mathrm{Z}$ direction. Although body height and quad bike experience strengthened a multivariate model slightly $\left(R^{2}=0.376\right)$ the effect was only minor and non-significant. Furthermore, body mass alone presented a univariate model $\left(\mathrm{R}^{2}=0.340\right)$ similar to BMI $\left(\mathrm{R}^{2}=0.337\right)$. Thus the predominant effect in this controlled fieldwork experiment (same track, same vehicle, same distance, same tyre pressure, similar riding time) was the influence of increased body mass in attenuating a significant percentage of vibration exposure in the $\mathrm{Z}$ direction.

The FFT analysis also demonstrated the presence of Zaxis resonant frequencies peaking at $3.72 \mathrm{~m} / \mathrm{s}^{2}$ and $4.0 \mathrm{~Hz}$ as well as lower amplitude peak accelerations detected in the $\mathrm{X}$ and $\mathrm{Y}$ axis in the lower frequency of $2.50 \mathrm{~Hz}$. These frequencies have been described as spinal resonant frequencies associated with injury risk as well as subjective discomfort in the vertical, fore-and-aft and lateral directions [34-36] particularly when the worker is exposed to these resonant frequencies for longer daily exposure periods.

In order to minimise for extrinsic factors such as vehicle type, track conditions and tyre pressure [10, 37, 38] all participants drove the same quad bike with a pre-set tyre pressure on the same test route. Although previous literature has reported relationships between driving experience, age of the driver, and vibration exposure $[6,10]$, there was no statistically significant evidence for this in this study. Thus 
the standardized test route and driving instructions are likely to have reduced behavioral effects associated with age and driving experience [39]. While this association between body mass and $\mathrm{VDV}_{\mathrm{Z}}$ is moderately strong and explains close to $34 \%$ of the variance for this vertical vibration measure it must also be recognized that $66 \%$ of vibration exposure is not explained by weight. Interestingly previous research indicates body mass had little effect on vibration exposure in the uni and multi-variate models when the rural workers were free to use their own vehicles, in their normal farm environment, undertaking their own daily chores, choosing their own vehicle and driving paths and driving at their own self-selected speed [9, 10]. This shows that a substantial number of factors can potentially influence statistical models for quad bike vibration exposure and that body mass is but one of these factors. Where choice is associated with vibration exposure (e.g. choice of driving path, tasks, and/or velocity) and where the demands of farm productivity can force the worker into making difficult task and time allocation choices, it is likely that behavioral factors will also have a strong influence on vibration exposure [39].

This research is consistent with previous laboratory results which demonstrate negative relationships between body mass, transmission coefficient and seat effective amplitude transmissibility $[19,20,22]$ as well as the positive relationships seen between body mass and vibration measures of total absorbed power, mechanical impedance and apparent mass [21-26]. These laboratory results thus support a negative relationship between body mass and vibration exposure. Two previous (albeit non-farming) field studies are contradictory, with one (taxi drivers) demonstrating a negative relationship and the other (fork-lift trucks) showing no relationship [19, 29]. However, these were conducted under different test conditions, routes and vehicles; with markedly different sample sizes which will likely have influenced vibration record and outcomes. A further small number of field studies (small samples) using a standardized test vehicle (bus drivers/fork-lift trucks) and test route also found contradictory effect for body mass on vibration exposure $[30,31]$. In contrast to the majority of these other studies the current research used a larger sample size and standardized for possible effects of extrinsic confounding factors such as: test farm, test route, vehicle (quad bike) as well as minimizing for driving speed, and thus attempted to isolate for the influence of personal, anthropometric and work experience variables.

The literature suggests occupational WBV, body mass or BMI are individual risk factors in the development of low back disorders [2, 15, 40]. Surprisingly recent evidence has found no association between WBV, BMI and low back pain in professional drivers [18]. It is possible that this recent finding could be explained in part, by the results of the current study, where increased body mass is significantly and negatively associated with vibration exposure at least in light-weight quad bikes in on-farm conditions.

The strengths of this study include: controlling for intrinsic and extrinsic factors such as driving instructions, standardized vehicle, validity of farm terrain, and adequate standardized exposure period. The limitations include a modest sample size $(n=34)$ thus reducing generalisability to the larger work force, the use of surveyed self-reported measures (including body mass, body height, driving experience) where evidence for reliability, validity and accuracy of self reported anthropometric measures are equivocal [41-44], as well as the use of a pragmatic and single sex (males) sample. Further research with a larger sample will be required to clarify these issues.

\section{CONCLUSION}

Body mass is significantly associated with quad bike induced WBV (expressed as $1 \mathrm{hrVDV}_{\mathrm{Z}}$ ) in a group of New Zealand rural workers. Other intrinsic factors such as body height, age and quad bike experience were not associated with vibration exposure. These results for body mass should be considered by others undertaking WBV research on small vehicle vibration exposures. Reduction of vibration exposures is considered an ergonomic intervention of importance in drivers of commercial vehicles. Attenuation of vibration by body mass alone may need to be factored into design of seating and suspension systems for small on-farm vehicles.

\section{ACKNOWLEDGEMENTS}

This research was part funded by:

1. The University of Otago Physiotherapy Research Fund.

2. A University of Otago PhD Scholarship awarded to Ramakrishnan Mani.

\section{REFERENCES}

[1] Mani R, Milosavljevic S, Sullivan SJ. The effect of occupational whole-body vibration on standing balance: A systematic review. Int J Ind Ergon 2010; 40 (6): 698-709.

[2] Notbohm G, Schwarze S, Albers M. Whole-body vibration and risk of disorders of the lumbar spine: Findings from the reanalysis of the epidemiological study "Whole-Body Vibration. Ganzkorperschwingungen und das Risiko bandscheibenbedingter Erkrankungen: Erkenntnisse aus einer Reanalyse der epidemiologischen Studie Ganzkorpervibration 2009; 44 (6): 327-35.

[3] Kuisma M, Karppinen J, Haapea M, et al. Are the determinants of vertebral endplate changes and severe disc degeneration in the lumbar spine the same? A magnetic resonance imaging study in middle-aged male workers. BMC Musculoskelet Disord 2008; 9: 51.

[4] Seidel H. On the relationship between whole-body vibration exposure and spinal health risk. Ind Health 2005; 43 (3): 361-77.

[5] Bovenzi M. Metrics of whole-body vibration and exposureresponse relationship for low back pain in professional drivers: A prospective cohort study. Int Arch Occup Environ Health 2009; 82 (7): 893-917.

[6] Tiemessen IJ, Hulshof CTJ, Frings-Dresen MHW. An overview of strategies to reduce whole-body vibration exposure on drivers: A systematic review. Int J Ind Ergon 2007; 37 (3): 245-56.

[7] Moore DJ. A systems analysis of Quad bike loss of control events on New Zealand farms. PhD[Thesis]. Auckland, New Zealand: Massey University; 2007.

[8] Milosavljevic S, Bergman F, Rehn B, Carman AB. All-terrain vehicle use in agriculture: Exposure to whole body vibration and mechanical shock. Appl Ergon 2010; 41 (4): 530-5.

[9] Milosavljevic S, McBribe D, Bagheri N, et al. Exposure to whole body vibration and mechanical shock: a field study of quad bike use in agriculture. Ann Occup Hyg (In press).

[10] Milosavljevic S, McBribe D, Moore D, et al. Farmers and quad bikes: vibrations, shocks and loss of vehicle control. Centre for Physiotherapy Research, University of Otago 2010; Report No: ISBN 978-0-473-16653-3.

[11] European Union. Guide to good practice on whole body vibration. Directive 2002/44/EC on minimum health and safety, European Commission Directorate General Employment, Social Affairs and Equal Opportunities; 2006. 
[12] Rehn B, Bergdahl IA, Ahlgren C, et al. Musculoskeletal symptoms among drivers of all-terrain vehicles. J Sound Vib 2002; 253 (1): 21-9.

[13] Pope MH, Magnusson M, Wilder DG. Low back pain and whole body vibration. Clin Orthop Relat Res 1998; (354): 241-8.

[14] Johanning E, Landsbergis P, Fischer S, Christ E, Gores B, Luhrman R. Whole-body vibration and ergonomic study of US railroad locomotives. J Sound Vib 2006; 298 (3): 594-600.

[15] Da Costa BR, Vieira ER. Risk factors for work-related musculoskeletal disorders: A systematic review of recent longitudinal studies. Am J Ind Med 2009; 53 (3): 285-323.

[16] Battie MC, Videman T, Kaprio J, et al. The Twin Spine Study: Contributions to a changing view of disc degeneration. Spine J 2009; 9 (1): 47-59.

[17] Bovenzi M, Rui F, Negro C, et al. An epidemiological study of low back pain in professional drivers. J Sound Vib 2006; 298 (3): 51439.

[18] Noorloos D, Tersteeg L, Tiemessen IJH, Hulshof CTJ, FringsDresen MHW. Does body mass index increase the risk of low back pain in a population exposed to whole body vibration? Appl Ergon 2008; 39 (6): 779-85.

[19] Burdorf A, Swuste P. The effect of seat suspension on exposure to whole-body vibration of professional drivers. Ann Occup Hyg 1993; 37 (1): 45-55.

[20] Huston DR, Johnson CC, Wood MA, Zhao X. Vibration attenuating characteristics of air filled seat cushions. J Sound Vib 1999; 222 (2): 333-40.

[21] Holmlund P, Lundstrom R, Lindberg L. Mechanical impedance of the human body in vertical direction. Appl Ergon 2000; 31 (4): 415-22.

[22] Bluthner R, Hinz B, Menzel G, Schust M, Seidel H. On the significance of body mass and vibration magnitude for acceleration transmission of vibration through seats with horizontal suspensions. J Sound Vib 2006; 298 (3): 627-37.

[23] Wang W, Rakheja S, Boileau PE. The role of seat geometry and posture on the mechanical energy absorption characteristics of seated occupants under vertical vibration. Int J Ind Ergon 2006; 36 (2): 171-84.

[24] Rakheja, S, Mandapuram S, Dong RG. Energy absorption of seated occupants exposed to horizontal vibration and role of back support condition. Ind Health 2008; 46 (6): 550-66.

[25] Toward MGR, Griffin MJ. Apparent mass of the human body in the vertical direction: Inter-subject variability. J Sound Vib doi: 10.1016/j.jsv.2010.08.041.

[26] Lundstrom R, Holmlund P. Absorption of energy during vertical whole-body vibration exposure. J Biomech 1998; 31 (4): 317-26.

[27] Boileau PE, Rakheja S. Vibration attenuation performance of suspension seats for off-road forestry vehicles. Int J Ind Ergon 1990; 5 (3): 275-91.
[28] Malchaire J, Piette A, Mullier I. Vibration exposure on fork-lift trucks. Ann Occup Hyg 1996; 40 (1): 79-91.

[29] Chen JC, Chang WR, Shih TS, et al. Predictors of whole-body vibration levels among urban taxi drivers. Ergonomics 2003; 46 (11): 1075-90.

[30] Blood RP, Ploger JD, Johnson PW. Whole body vibration exposures in fork-lift operators: comparison of a mechanical and air suspension seat. Ergonomics 2010; 53 (11): 1385-94.

[31] Blood RP, Ploger JD, Yost MG, Ching RP, Johnson PW. Whole body vibration exposures in metropolitan bus drivers: A comparison of three seats. J Sound Vib 2010; 329 (1): 109-20.

[32] Akram DS, Astrup AV, Atinmo T, et al. Obesity: Preventing and managing the global epidemic. World Health Organization Technical Report Series 2000.

[33] Mansfield, N. Human response to vibration. London: CRC Press 2004; pp. 115.

[34] Wilder DG, Woodworth BB, Frymoyer JW, Pope MH. Vibration and the human spine. Spine 1982; 7 (3): 243-54.

[35] Fairley TE, Griffin MJ. The apparent mass of the seated human body in the fore-and-aft and lateral directions. J Sound Vib 1990 139: 299-306.

[36] Subashi GHMJ, Nawayseh N, Matsumoto Y, Griffin MJ. Nonlinear subjective and dynamic responses of seated subjects exposed to horizontal whole-body vibration. J Sound Vib 2009; 321 (1-2): 416-34.

[37] Paddan, G. S. and M. J. Griffin. Evaluation of whole-body vibration in vehicles. J Sound Vib 2002; 253 (1): 195-213.

[38] Sherwin LM, Owende PMO, Kanali CL, Lyons J, Ward SM. Influence of tyre inflation pressure on whole-body vibrations transmitted to the operator in a cut-to-length timber harvester. Appl Ergon 2004; 35 (3): 253-61.

[39] Tiemessen IJH, Hulshof CTJ, Frings-Dresen MHW. Effectiveness of an occupational health intervention program to reduce whole body vibration exposure: An evaluation study with a controlled pretest-post-test design. Am J Ind Med 2009; 52 (12): 943-52.

[40] Heuch I, Hagen K, Nygaard O, Zwart JA. The impact of body mass index on the prevalence of low back pain: The HUNT study. Spine 2010; 35 (7): 764-8.

[41] Stunkard AJ, Albaum JM. The accuracy of self-reported weights. Am J Clin Nutr 1981; 34 (8): 1593-999.

[42] Stewart AL. The reliability and validity of self-reported weight and height. J Chronic Dis 1982; 35 (4): 295-309.

[43] Nieto-Garcia FJ, Bush TL, Keyl PM. Body Mass definitions of obesity: sensitivity and specificity using self-reported weight and height. Epidemiology 1990; 1 (2): 146-52.

[44] Palta M, Prineas RJ, Berman R, Hannan P. Comparison of selfreported and measured height and weight. Am J Epidemiol 1982; 115 (2): 223-30

This is an open access article licensed under the terms of the Creative Commons Attribution Non-Commercial License (http://creativecommons.org/licenses/ by-nc/3.0/) which permits unrestricted, non-commercial use, distribution and reproduction in any medium, provided the work is properly cited. 